\title{
AN ASSESSMENT OF RELATIONS BETWEEN SMART GROWTH AND SOCIAL COHESION IN REGIONAL DIMENSION ${ }^{1}$
}

The objective of the study is to provide an assessment of relations combining smart growth and social cohesion, as well as to identify how and which social cohesion dimensions are involved in the relationships with smart growth. The analysis covered the period 2003-2013. Smart growth was described by using three pillars: smart specialization, creativity and innovation, whereas social cohesion was defined from the perspective of the most important problems grouped in five categories: income, young people in the labour market, unemployment, gender equality and demography. Panel (LSDV) and cross-section models were used for the assessment of relations between smart growth and social cohesion. LSDV models allow for including in the model, specific for a given region, the factors derived from location, resources, economic, cultural and political determinants, as well as other aspects which are unobservable and not included in the model. One-year models allow for identifying cross-section relations. The obtained results emphasize the significance of growth factors, related to human capital, for social cohesion. Regional creativity, manifested by the skills and education of the workforce presented the highest consistency with social cohesion improvement (especially in terms of unemployment - including youth unemployment - and income categories). The relations with smart specialization, defined as human resources and human capital in high and medium high-technology manufacturing and knowledge-intensive services, were also recognized as significant. The least significant relationships were identified for regional innovation, estimated based on expenditure on research and development in the business sector.

Keywords: social cohesion, smart growth, EU regions

DOI: $10.15611 /$ aoe.2018.1.02

\section{SMART GROWTH VERSUS SOCIAL COHESION - INTRODUCTION}

The European Union (EU) member states face numerous diversified challenges regarding their growth. The activities included in the Europe 2020 strategy for smart, sustainable and inclusive growth present the

\footnotetext{
* Department of Regional Economy, Wrocław University of Economics.

${ }^{1}$ The first version of the study was conducted within the framework of the research grant NCN No. 2011/01/B/HS4/04743 entitled: European regional space classification in the perspective of smart growth concept - a dynamic approach.
} 
response to developmental problems. Smart growth refers to development based on the factors of key significance for competitiveness and long-term growth, facilitating knowledge creation, research and new technologies development. For this purpose it is indispensable to strengthen and develop well qualified personnel which require adequate financial resources and the establishment of organizational and technical facilities for science and education. Three spheres supporting smart growth have been identified: education (creating conditions and encouraging education and qualification upgrading), research and innovation (launching new products and services to stimulate the increase in economic development level and employment and to support solving both social and environmental problems), as well as digital society (the widespread implementation of information and communication technologies enhancing efficiency and facilitating communication, economic exchange, science, etc.).

The Europe 2020 strategy defines, for the entire European Union (EU), three quantitative headline targets to support smart growth:

1) a higher total level of public and private investment in research and development (R\&D) of up to $3 \%$ of the EU's GDP and ensuring better conditions for $\mathrm{R} \& \mathrm{D}$ and innovation;

2) an increase in the employment rate of the population aged 20-64 of up to $75 \%$, especially by means of more women, youth, senior citizens, lowskilled workers and legal immigrants entering the labour market;

3) a better education level provision by reducing the percentage of young people dropping out of the education system prematurely to below $10 \%$ and striving to ensure that at least $40 \%$ of the population aged $30-34$ graduate from tertiary education (or equivalent) institutions.

These values differ in the cross-section of particular countries and in the case of GDP for research and development they vary from $0.5 \%$ (Cyprus) to $4 \%$ (Sweden, Finland), for employment rate at the level of $62.9 \%$ (Croatia) to $80 \%$ and more (Sweden, Netherlands, Denmark), and for youth dropping out of school prematurely from $4 \%-4.5 \%$ (Croatia, Poland) to $16 \%$ (Italy).

Problems referring to innovation and human capital present a subject matter of interest for scientists who have been analysing these issues theoretically for many years, especially in the context of regional and national developmental disproportions. The review of selected regional development theories regarding the role played by innovation was presented, among others, by Dominiak et al. (2012), Kawa (2007) and Strahl (2010), while human capital aspects were discussed by e.g. Herbst (2007) and Cichy (2008). Among the more important regional development theories - having 
many references in professional literature and citations in regional research the following can be listed: the new theory of endogenous growth by Romer $(1986,1990)$ and Lucas $(1988)$, the concept of a new geographic economy by Krugman $(1991,1995)$, the concept of a new policy for endogenous development by Molle and Cappelin (1988), the theory of growth poles by Perroux (1995), as well as the learning region theory by Florida (2000) and Asheim (1995).

Smart growth is observed as an opportunity for the development of competitive economy areas implementing knowledge and new ideas, i.e. factors facilitating endogenous growth in the long-term perspective - Romer $(1986,1990)$. The key role is played here by human and real capital which opens opportunities for growth. Developmental inequalities in space refer to disparities in the level of capital accumulation and enterprise technological development as well as knowledge resources of non-productive enterprises located within a given region. Therefore, a hypothesis may be put forward that regions featuring extensive human capital potential, high research and development expenditure, advanced knowledge and related infrastructure, represent areas characterized by a high economic growth level. Smart growth can be discussed from the perspective of its various dimensions including smart specialization, both as an economic concept and a policy framework, which provides a novel avenue to pursue the dual objectives of fiscal constraint and investment in longer-term growth potential in the context of rapid technological change and globalization (OECD, 2013). Regional policy contributing to smart growth in Europe 2020 is also of great importance. As provided in the Communication of European Commission (2010), which sets out the role of Regional Policy in implementing the Europe 2020 strategy in the area of smart growth, "it does so by creating favorable conditions for innovation, education and research so encouraging R\&D and knowledgeintensive investment and moves towards higher value-added activities. It can therefore help to meet the major challenge for Member States and regions of increasing innovation capacity and $R \& D$ in businesses and strengthening their links with universities and research centers".

Development cannot involve increasing economy just for its own sake. It should result in improving the life quality of people in all spheres, including the social sphere, which characterizes the position of an individual in its milieu. It is expected that social cohesion is one of the consequences of economic growth policy. Economic and social aspects are inextricably related and overlapping. Following the approach presented by Myrdal (1957) 
the process of social and economic development is determined by the social goals accepted by the society. Myrdal indicates that "a theory of underdevelopment and development which works only with 'economic' variables is for logical reasons doomed to be unrealistic and thus irrelevant".

Social cohesion represents one of the Europe 2020 Strategy flagships including the target indicating the need for inclusive growth, which should manifest itself in supporting an economy featuring a high employment level and ensuring economic, social and territorial cohesion. Social dimension covers many diversified aspects visible in the life quality of local residents. Therefore, the question arises whether smart growth enhances social cohesion strengthening, and if so, which social cohesion aspects present the strongest relationship with smart growth. The problems analysed in terms of social cohesion are also combined with the economy and job market. This refers to such areas as employment structure, unemployment and households' income. While assessing the relations occurring between these two phenomena it is difficult to determine clearly the impact direction and answer the question of whether smart growth strengthens social cohesion, or it is social cohesion which enhances growth in areas related to knowledge, human capital and innovation creating conditions for smart growth. These phenomena influence one another. In general, it can be stated that smart growth is perceived as one of the tools for the accomplishment of social and economic cohesion. On the other hand, concentrating development in knowledge and high-tech sectors is not possible unless a certain level of development is achieved in the aspects related to, for example, the creation of human capital.

The objective of this study is to provide the assessment of the relations combining smart growth and social cohesion, as well as to identify which social cohesion dimensions enter into relations with smart growth. The following research questions were put forward:

1. Do regional EU economies strengthen their potential in terms of smart growth?

2. Is the improvement of the social dimension of the economy visible in a cross-section of EU regions?

3. Did the 2008 crisis have a major impact on the tendencies for strengthening smart growth and social cohesion?

4. Does the development of regions, in line with the idea of smart growth, facilitate strengthening social cohesion? 


\section{RESEARCH PROCEDURE}

While analysing the problems of development, the focus is on both the changes and factors of the situation's improvement. Regional development should be understood as "the process of positive quantitative growth and qualitative progress occurring in a region representing a supra-local socioterritorial system identified by the specific spatial characteristics, economy structure and social ties resulting from a common regional identity" (Strahl, 1998).

Regional development is understood as: an increase in socio-economic potential, sustainable improvement of competitiveness, better life quality of residents, and the elimination of negative internal and external variations in the level of development. This analysis has been developed to identify the changes and relationships between one of the key areas of smart growth and social cohesion which directly affect the life quality of the population. The research was conducted following four subsequent stages:

1. defining the problem based on the study of the bibliography and strategical documents and collecting statistical data for the description of social cohesion and smart growth,

2. constructing synthetic measures (SGM) of smart growth and social cohesion,

3. statistical analysis of the average level and interregional variations based on SGM,

4. the estimation of econometric models describing relations between social cohesion and smart growth.

\section{Statistical data}

The indicators and smart growth pillars defined in the study by Markowska et al. (2014) were the starting point for the research results discussed in this paper. In the above-mentioned study, the inspiration for defining research areas and smart growth measures was the approach adopted by the World Bank, Chen (2005) where the measurement methodology for the difficult to quantify knowledge-based economy was based on identifying its pillars and within these pillars the lists of measures best reflecting its character, were indicated. In the aforementioned study the analysis of strategic goals, flagship initiatives for smart growth in the EU and statistical database resources for European NUTS 2 level 2 (Eurostat) were analyzed in order to define the pillars and the list of measures allowing 
the measurement of smart growth. This allowed the authors to distinguish three pillars of smart growth indicators (smart specialization, creativity and innovation) as well as economic and social cohesion measures.

Having considered the above presented proposal for the measurement of smart growth, based on substantive merits and also data availability and their completeness in the EUROSTAT data base, the diagnostic characteristics were chosen and defined for the purposes of describing smart growth and social cohesion pillars in NUTS-2 regions. Eleven diagnostic characteristics were selected and grouped in eight categories $\left(k=k^{s}+k^{l} ; s=1,2, \ldots, S\right.$; $l=1,2, \ldots, L)$ : three $k^{l}$ categories referring to smart growth pillar and five $k^{s}$ categories describing specific social cohesion aspects.

All variables describing smart growth pillars represent stimulants, i.e. their higher values strengthen development processes focused on an innovation and knowledge-based economy. Two diagnostic characteristics (indicators) were selected as smart growth measures in pillar I - smart specialization $\left(K_{S S}\right)$ - the indicator (based on data htec_emp_reg2):

- KIS - employment in knowledge-intensive services as a share of total employment (\%),

- HTMS - employment in high and medium high-technology manufacturing as a share of total employment (\%).

The variables above characterize the scale of employment in enterprises implementing high-tech knowledge and require ongoing expenditure in research and development. Therefore, it can be stated that they result from market and competition pressure exerted on developing activities based on knowledge and innovation. Regions featuring high level of employment in high-tech sectors have both a competitive advantage and an adequate base for long-term development. The functioning of a well-developed high-tech industry sector influences the strengthening of human capital in the region, as well as stimulates the establishment of research clusters which, in a natural way, create relationships between science and entrepreneurship, and facilitate the exchange of ideas and the creation of new values. Such conditions are ideal for attracting new investments which require strong scientific backup, since "enterprises should (...) function in an environment which effectively supports innovative activities by disseminating knowledge and information. Personal contacts are observed as the crucial factor enhancing efficiency and swift information transfer and, therefore, close relations between stakeholders" (Bąkowski at al., 2007). This supports the construction of growth poles. 
In order to measure pillar II of smart growth - regional creativity $\left(K_{C R}\right)$, the characteristics describing human capital in a region were applied as the basic causative factor related to creativity responsible for the construction and implementation of innovative solutions. Professional literature offers different definitions of human capital. They mainly focus on qualitative attributes (as opposed to human resources which are of a quantitative nature) and refer to knowledge, skills or experience, but also to the ability of management and functioning in a dynamically changing environment, to openness for new challenges or health condition (for more see Herbst, 2007). The consequences of the adequate presence of human capital resources in a region is manifested in the development of institutions (enterprises) which implement or create "knowledge" in a direct way and are capable of introducing innovative solutions. This refers to manufacturing and service enterprises, but also to public administration which supports and regulates socio-economic life. Therefore, human capital stands for a creative factor exerting an impact on all areas of socioeconomic life. This is of primary significance regarding all possible changes. It can be assumed that regions featuring high quality human capital carry the potential for long-term development. The implementation of innovative solutions stimulates the improvement of the quality of human capital by transferring knowledge and new skills and thus gaining experience in a particular field. This cycle is based on feedback resulting in the strengthening of human capital quality and therefore increasing regional development power. As Świtała (2007) observed, "owing to a very long investment cycle and low human capital mobility (...) a thesis should be put forward that in the coming several decades it is the differences in regional human capital which will decide about interregional disproportions". This statement points to human capital as a strong determining factor referring to the regional development potential. For this reason its continuous development and improvement is so important in order to open opportunities for ongoing growth and also to encourage investment. The study includes the following characteristics (indicators) describing pillar II of smart growth - regional creativity $\left(K_{C R}\right)$ :

- TETR - share of tertiary education employment in total employment in a region (\%) (the indicator based on data: lfst_r_lfe2eedu),

- HRST - human resources in science and technology as a percentage of the active population (\%) refers to persons fulfilling one of the following conditions: either having successfully completed tertiary education level 
in the S\&T field of study, although not formally qualified as above, or employed in an S\&T occupation where the above qualifications are normally required (hrst_st_rcat).

Tertiary education graduates present universal capital, which can be taken advantage of in all sectors of economy and also in the field of social activity. Human resources in science and technology, on the other hand, present the share of capital which contributes, in particular, to the sphere of science and technological development.

The following measure was used for pillar III - the potential and capacity for innovation $\left(K_{I N N}\right)$ :

- $R \& D$ - intramural research and development expenditure (GERD) in the enterprise sector (\% of $G D P$ ); the indicator based on data: rd_e_gerdreg.

This characteristic identifies regions involved in activities focused on the enhancement of research and development. Only the expenditure incurred by enterprises was considered, i.e. outlays resulting from internal developmental and competitive power, thus assigning the key significance of expenditure incurred by economic entities to regional developments. The effects of research and development results exert a positive influence on the position of a region hosting such a research base. In such a region the respective jobs are opened and new ideas are created. In the next stage, the $R \& D$ activity results can be transferred to other regions. Products in the form of knowledge and inventions are mobile and can stimulate the development of many other areas. However, the research base established in a particular region and the related infrastructure, as well as human and social capital, are permanently associated with such region, representing its developmental and competitive advantage.

Social cohesion is a complex phenomenon covering many aspects. This study defines five problem categories to characterize social cohesion. Each of them was assigned certain diagnostic characteristics (Table 1).

While assessing social cohesion it is worth paying attention to the importance of regional growth measures defined within the framework of this approach. The list of social cohesion's diagnostic characteristics covers both positive aspects and negative phenomena. The first group includes demographic changes and income. They function as stimulants and their higher values should be evaluated as stimulating development and cohesion. The second group includes phenomena of a negative impact, e.g. gender inequality and unemployment, including unemployment among young people. They function as destimulants. 
Table 1

A list of social cohesion categories and their diagnostic characteristics

\begin{tabular}{|c|c|c|c|}
\hline $\begin{array}{l}\text { Social } \\
\text { cohesion } \\
\text { categories }\end{array}$ & $\begin{array}{l}\text { The components of particular } \\
\text { social cohesion categories } \\
\text { (diagnostic characteristics) } \\
\text { [EUROSTAT table] }\end{array}$ & $\begin{array}{l}\text { Type of } \\
\text { diagnostic } \\
\text { characteristic }\end{array}$ & $\begin{array}{l}\text { The importance of diagnostic } \\
\text { characteristics for social cohesion }\end{array}$ \\
\hline $\begin{array}{l}\text { Income } \\
\left(K_{I N C O M}\right)\end{array}$ & $\begin{array}{l}\text { INCOM - net (uses) disposable } \\
\text { income of households } \\
\text { (purchasing power standard } \\
\text { based on final consumption per } \\
\text { inhabitant) [nama_10r_2hhinc] }\end{array}$ & Stimulant & $\begin{array}{l}\text { Higher income allows for meeting } \\
\text { more needs (purchase of goods and } \\
\text { services) at a higher level }\end{array}$ \\
\hline $\begin{array}{l}\text { Youth in the } \\
\text { labour market } \\
\left(K_{U N E M 24}\right)\end{array}$ & $\begin{array}{l}\text { UNEM24 - unemployment rate } \\
\text { among young people (aged } 15 \\
\text { - 24) (\%) (LFS series) } \\
\text { [1fst_r_lfu3rt] }\end{array}$ & Destimulant & $\begin{array}{l}\text { The provision of equal chances in } \\
\text { accessing the labour market for all } \\
\text { social groups and especially for } \\
\text { individuals who are starting their } \\
\text { professional career and searching for } \\
\text { their place on the labour market } \\
\text { represents an important component of } \\
\text { cohesion }\end{array}$ \\
\hline $\begin{array}{l}\text { Gender } \\
\text { equality } \\
\left(K_{G E N}\right)\end{array}$ & $\begin{array}{l}G E N-\text { difference in } \\
\text { employment rate of men and } \\
\text { women aged } 20-64 \text { (absolute } \\
\text { value }(K-M) / M(\%)) \\
\text { [lfst_r_lfe2emprt] }\end{array}$ & Destimulant & $\begin{array}{l}\text { Gender equality is an important } \\
\text { component of freedom and ensuring } \\
\text { equal opportunities in accessing the } \\
\text { labour market by all social groups. The } \\
\text { activities aimed at guaranteeing labour } \\
\text { market access for women facilitate } \\
\text { creating conditions favourable for men } \\
\text { and women combining the fulfilment of } \\
\text { professional aspirations and family life }\end{array}$ \\
\hline $\begin{array}{l}\text { Unemployment } \\
\left(K_{U N E M}\right)\end{array}$ & $\begin{array}{l}\text { UNEM-unemployment rate } \\
\text { (\%) [lfst_r_lfu3rt] } \\
\text { UNEM_long-long-term } \\
\text { unemployment rate (\%) (LFS } \\
\text { series) [lfst_r_lfu2ltu] }\end{array}$ & Destimulant & $\begin{array}{l}\text { Unemployment, especially long-term, } \\
\text { results in poverty and adversely } \\
\text { influences the social position of the } \\
\text { affected population }\end{array}$ \\
\hline $\begin{array}{l}\text { Demography } \\
\left(K_{D E M}\right)\end{array}$ & $\begin{array}{l}D E M-\text { total population growth } \\
\text { rate index (previous year }= \\
100) \\
\text { [demo_r_d2jan] }\end{array}$ & Stimulant & $\begin{array}{l}\text { Indicates population growth rate areas } \\
\text { which can be interpreted as areas } \\
\text { where the population is willing to } \\
\text { settle, and the positive processes of } \\
\text { demographic development are } \\
\text { observed. The areas are perceived as } \\
\text { featuring favourable living conditions. }\end{array}$ \\
\hline
\end{tabular}

Source: author's compilation.

The Eurostat ${ }^{2}$ data base was the source of data for all variables. In the course of database construction, certain data completeness problems were encountered referring to e.g. the EU-LFS statistics. The EU-LFS statistics present an overall high quality. National LFS surveys are considered to be the reliable sources applying high standards with regard to methodology.

\footnotetext{
${ }^{2} \mathrm{http} / /$ epp.eurostat.ec.europa.eu/portal/page/portal/eurostat/home/.
} 
However, the EU-LFS, like any survey, is based on a sample of population. Therefore, the results are subject to the usual types of errors associated with random sampling. LFS is more appropriate for measuring participation in the labour market (employment rates, activity rates, flows between employment and unemployment, etc.), demographic or social breakdowns (e.g. by age, gender or educational level), and it is more suitable for socio-demographic studies. The final choice of regions and the period under analysis was determined by the substantive relevance and availability of statistical data. The analysed period was 2003-2013. The study covered 174 out of 271 European Union regions at NUTS-2 level, which constituted 64\% of the EU regions' population. The spatial system of regions covered by the analysis is presented in Figure 2.

Data gaps were supplemented by extra and interpolation methods. ${ }^{3}$ Due to the fact that the analyses were conducted on a sample of regions, the main focus was shifted to the assessment of parameter values for the entire analysed population, reducing to the minimum the information on the situation of particular regions. Social cohesion and smart growth were approximated by synthetic growth measures (SGM). SGM allow the aggregation of many variables describing the phenomenon using one measure. In the study, a single measure was used to describe some of the phenomena. In such cases SGM was identical with the variable values after unitarization (see below). Such an approach allowed for the aggregation of variables and the presentation of each variable value in the range from 0 to 1 in the entire analysed period.

At the first stage of synthetic growth measures, $S G M$ construction for diagnostic characteristics was performed by means of the unitarization procedure based on the formula presented bellow; more in Hellwig (1968) and Zeliaś (2000):

$$
z_{i t j}=\frac{x_{i t j}-\min _{i} x_{i t j}}{\max _{i} x_{i t j}-\min _{i} x_{i t j}},
$$

\footnotetext{
${ }^{3}$ It was adopted that the data were supplemented only if there were less than three consecutive observations. In the case of extrapolation, the missing values were defined at the same level as the observations of the nearest available periods, or possibly the values were determined based on the trend function (however, only in a situation when the variance of the variable value in a given region was small). For interpolation, when only one value was missing in the middle of the series the mean value was calculated, when two values had to be completed the approach adopted for extrapolation in the calculation of only one of the two values was combined and only then the mean of the two proximal values was used.
} 
where $z_{i t j}$ - the value of $j$-th diagnostic characteristic (variable), $j=1,2, \ldots, m$ in the $i$-th object (region), $i=1,2, \ldots, N$ in $t$-th year $(t=1,2, \ldots, T)$ after unitization; $x_{i t j}-j$-th diagnostic characteristic realization in $i$-th object; min $x_{i t j}\left(\max x_{i t j}\right)$ - the smallest (the largest) value of $j$-th $x_{i t j}$ variable.

In the next step, the most favourable values were identified for each variable considering all regions in all the analysed years (Walesiak 2006, Bal-Domańska at al. 2011), i.e. the most favourable values regarding stimulants were accepted as the maximum ones, and in the case of destimulants - minimum values. This allowed for defining the hypothetical regions-pattern with the most favourable values $\left(z_{0}\right)$ for each variable within the framework of each social cohesion category or smart growth pillar. The common growth pattern formula allowed for the uniformity of measure values and the comparison of regional ranking in time.

Next, by means of growth pattern method implementation (standardised sum method), partial synthetic measures of growth $\left(S G M_{k}\right)$ were constructed for each $k^{S}$ social cohesion category $\left(S G M_{I N C O M}, S G M_{U N E M 24}, S G M_{G E N}\right.$, $S G M_{U N E M}$ and $\left.S G M_{D E M}\right)$ and $k^{l}$ regional smart growth $\left(S G M_{S S}=S S\right.$, $\left.S G M_{C R}=C R, S G M_{I N N}=I N N\right)$.

The resulting $S G M_{k}$ are standardised in the range [0;1], with higher measure values referring to a more favourable assessment of the situation. An $S G M_{k}$ value which equals 1 is identical with the value of the hypothetical regions-pattern.

The construction of $S G M_{k}$ allowed for preparing measures preferred by regions featuring the favourable level of each factor covered by a given category, e.g. including employment in knowledge-intensive services and medium high-technology manufacturing in smart specialization $S S$ pillar results in the higher ranking position of these regions which have both welldeveloped knowledge sectors (services and industry), while those specializing only in one type of operations will be rated relatively lower. Therefore, it was assumed that the regions featuring diversified high-tech specialization, which are supposed to be complementary for each other, are more competitive. In the case of the creative regions $(C R)$ pillar, the inclusion of both tertiary education human capital measures and constituting human resources in science and technology gave priority to regions which, on the one hand, have workers presenting a particular level of education and, on the other, have significant resources at their disposal for S\&T activities.

In the next step of the research procedure, the statistical analysis of the obtained SGM values in subsequent years was carried out (with particular emphasis on the first and last analysis period as well as in 2008-2009). An 
SGM assessment of development referred to the variables of an average level of the discussed phenomenon over the coming years, which allowed to identify the general development trends, the changes in the level of regional variations, and also to assess whether there occur any levelling processes in the level of regional development. At this stage the main emphasis was on the general trends over time, identified by mean values (mean, and 3-4 median in Figure 1), and variations in the cross-section of regions measured by the classical variation coefficient (defined as the relation of standard deviation and the mean value).

The econometric models allow the estimation of the direction and level of changes featuring relations between smart growth and social cohesion. The constructed models were characterized by three pillars of smart growth $S G M_{S M}^{l}=\left(S G M_{S S}, S G M_{C R}, S G M_{I N N}\right)$ explained by means of the social cohesion categories $S G M_{S O C}^{s}=\left(S G M_{I N C O M}, S G M_{U N E M}, S G M_{U N E M 24}\right.$, $\left.S G M_{G E N}, S G M_{D E M}\right)$. The estimation procedure was conducted following three stages.

I. At the first stage those social cohesion categories were defined, which indicated a statistically significant relationship with particular smart growth pillars. For this purpose the following panel model constructions were used separately for each social cohesion category:

$$
S G M_{S M, i t}^{l}=f\left(S G M_{S O C, i t}^{s}, \alpha_{\mathrm{i}}\right)+\varepsilon_{i t},
$$

where: $\alpha_{i}$ - constant in time individual (regional) effects for the $i$-th region $(i=1,2, \ldots, n)$.

On the basis of model (3) results it is possible to construct models covering social cohesion jointly, considering the statistically significant categories identified in models (3) following the panel model structure:

$$
S G M_{S M, i t}^{l}=f\left(\sum_{s=1}^{S} S G M_{S O C, i t}^{\mathrm{s}}, \alpha_{\mathrm{i}}\right)+\varepsilon_{i t} .
$$

Models defined in this way help to answer the question which of the social cohesion dimensions present statisticall significant relations with regional smart growth phenomena.

In models (3) and (4), smart growth was shown on the left side of the equations. This allowed for considering and identifying different social cohesion dimensions (categories) on the right side of the equations and analysing their simultaneous relation with particular smart growth pillars. 
II. The second stage of the study consisted in the influence of smart growth pillars on particular social cohesion categories in line with the following panel model structure:

$$
S G M_{S O C, i t}^{s}=f\left(\sum_{l=1}^{L} S G M_{S M, i t}^{l}, \alpha_{\mathrm{i}}\right)+\varepsilon_{i t} .
$$

The final structure of models (4) and (5) is defined following one of the sequential testing procedures: a posteriori elimination procedure (top-down approach, general to specific procedures $)^{4}$.

III. The final stage of the study consisted of the joint influence of smart growth pillars on particular social cohesion categories in line with the following cross-section model structure:

$$
S G M_{S O C, i}^{s}=f\left(S G M_{S M, i}^{l}\right)+\varepsilon_{i} .
$$

It was assumed that changes in the indicator values, illustrating the analysed phenomena occur in a proportional manner, thus the linear representation for all models was adopted. In addition, the linear dependence of the discussed relationships was justified by: the technical feasibility of the estimation for normalized variables ranging from 0 to 1 ; transparency of interpretation and comparability of the obtained results.

In order to estimate models (3)-(5), the $L S D V$ method (least squares with dummy variable) was applied; techniques typical for panel data: Hsiao (1986), Wooldridge (2002), Greene (2003), Dziechciarz (1993). Models (6) were estimated using OLS (ordinary least square).

To explain how much of the variability of a social cohesion/smart growth issues can be caused or explained by its relationship to smart growth/social cohesion factors, the coefficient of determination symbolized by $R^{2}$ was used. The coefficient of determination determines the degree of linear correlation of variables (goodness of fit) in regression analysis. In the case of panel models (LSDV), $R^{2}$ is a squared correlation coefficient of the dependent variable and its theoretical values computed using both the measure of the individual effects and the effects of the explicitly named regressors.

The estimation correctness of the model structural parameters depends on the degree of meeting the assumption of the adopted estimation method. Test

\footnotetext{
${ }^{4}$ For procedure description see e.g. Nowak (2006), Hendry and Doornik (2001). The method assumed the start from the largest model that is congruent with the application of a 'testing down' process, eliminating variables with p-value coefficients that are not statistically significant, leading to a simpler model.
} 
$F$ was applied to assess the significance of the group effects $\alpha_{i}$ in panel models (3)-(5) (Greene, 2003). Test $F$ allows to evaluate the significance of dummy variables referring to the individual effects for each studied object (region) for null hypothesis that the cross-sectional units all have common intercepts. They stand for different macroeconomic conditions resulting from a particular location, resources, socio-economic development level and type, management and other factors not covered by the model structure. Alternatively - according to $H_{1}$ - the model may have been estimated with $i$ dummy variables instead.

Durbin-Watson $(D W)$ test statistics (Baltagi, 2005) was used to examine autocorrelation of the first order random component over time in fixed effects panel models. Autocorrelation, i.e. a situation in which $\varepsilon_{t}$ random component from $t$ period is correlated with $\varepsilon_{t-1}\left(\mathrm{RHO}^{5}\right)$ the component from the previous period, is undesirable in the model, and can result in the overestimation of the structural parameters assessments. In order to minimize their possible negative effects in the case of all models, robust standard errors were used (Arellano, 2003 - HAC) robust to autocorrelation or/and heteroskedasticity.

\section{REGIONAL DIVERSIFICATION OF SOCIAL COHESION AND SMART DEVELOPMENT}

While initiating the assessment of social cohesion and smart growth relations, attention should be paid to particular factors to the diversification and their changes in time. For this reason Figures 1, 3 and 4 present box plots illustrating basic $S G M_{k}$ diversification statistics in the four extreme years of the study, i.e. 2003 (the initial year of the analysis) and 2008-2009 (the period of crisis), and 2013 (the end year of the conducted analysis).

The overall assessment of regional development level, within the framework of particular smart growth pillars, points to the extensive progress made by regions regarding creativity (less progress in the remaining two pillars). The regions made significant progress in this area by upgrading personnel qualifications and strengthening human capital and also simultaneously equalizing the level of regional creative resources (variation coefficient of $S G M_{C R}$ in 2003 amounted to $47.1 \%$, in $2008-38.4 \%, 2009-$ $37.8 \%$ and in $2013-37.1 \%$ ). The region of Inner London was ranked exceptionally high regarding creativity and, therefore, it is shown in Figure 1

\footnotetext{
${ }^{5}$ RHO should be close to zero.
} 
as an outlier. In 2003 the share of human resources in science and technology (HRST) in this region was 54\% in 2003 and $74 \%$ in 2013, and the percentage of working tertiary education graduates amounted to $48 \%$ in 2003 and $71 \%$ in 2013 . This region is definitely ahead of others regarding their human capital potential.

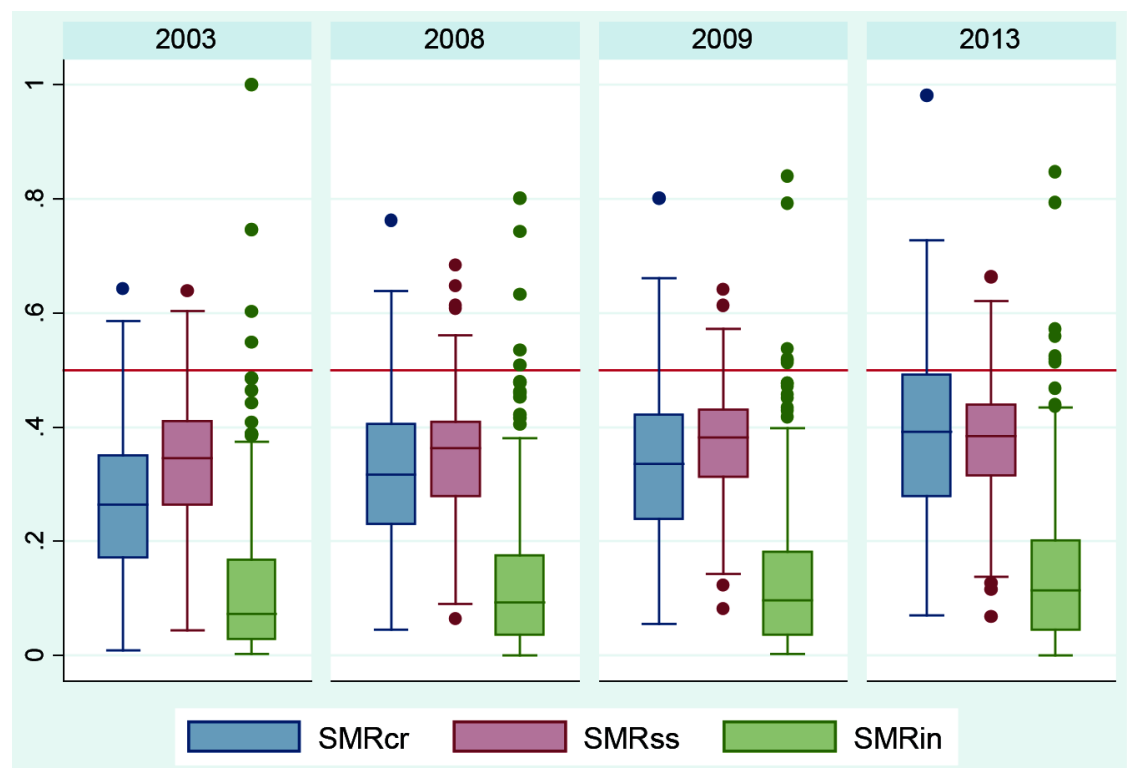

Figure 1. Synthetic growth measures for smart growth pillars (presented as stimulants) in 2003, 2008, 2009 and 2013

Source: author's compilation in STATA.

Only slight progress was made by regions in smart specialization. Five German regions were ranked ahead of others: Braunschweig, Karlsruhe, Studttart, Tübingen and Oberbayern. They attributed their position to the high share of employment in high and medium high-technology manufacturing (2013: between 12\%-19\%) and, at the same time, in knowledge-based services (2013: between 37\%-45\%).Therefore these regions are the leading ones as far as their growth level and human capital are concerned in both high and medium high-technology manufacturing and knowledge-intensive services. The equalization processes were also observed in the case of smart specialization (cohesion) equalizing the level of regional smart specialization (the variation coefficient of SGMss in 2003 amounted to $36.4 \%$, in $2008-33.1 \%, 2009-27.6 \%$ and in $2013-27.4 \%$ ). 


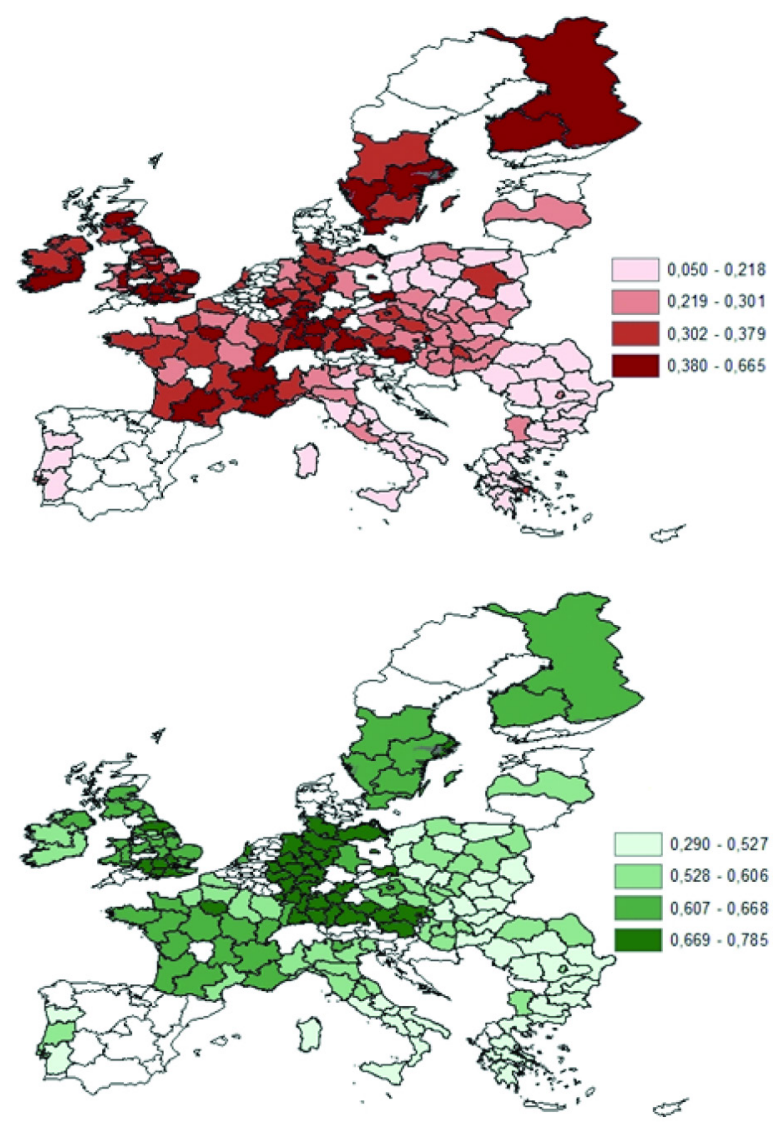

Figure 2. Synthetic growth measure for smart growth (SGMSD) (left) and for social cohesion (SGMSC) (right) in 2013

Source: author's compilation.

The 'regional innovation' pillar records a slight improvement in its general situation. The level of research and development expenditure presented as GDP percentage was small (the mean for the studied regions in 2003 amounted to $0.85 \%$, in 2013 it was slightly higher at $1.0 \%$ ) and also strongly diversified (variation coefficient at the level of 96\%-117\%). The group of several regions covering significantly higher $\mathrm{R} \& \mathrm{D}$ expenditure than others is clearly distinctive. In this group some German regions are also included (Stuttgart, Braunschweig, Oberbayern, Tübingen). Apart from these German regions the following ones also spent over 3\% of their GDP on R\&D (in at least one of the studied years): French Midi-Pyrénées, Swedish 
Sydsverige and Västsverige and in Britain East Anglia, Bedfordshire, Hertfordshire and Essex. It is worth emphasizing that in the period 20032013 , 35 regions (20\% of the analysed population) reported $R \& D$ expenditure in the business sector equal to or below $0.1 \%$. Among them were: 4 Bulgarian regions, 6 Greek, 2 Hungarian, 4 Italian, 11 Polish, 6 Romanian, 1 British and 1 Slovak.

Having analysed the spatial distribution of smart growth level, measured by the mean value of three partial synthetic measures $\left(S G M_{S M}=1 / 3 S G M_{C R}+\right.$ $+1 / 3 S G M_{S S}+1 / 3 S G M_{I N N}$ ) (Figure 2), the definitely lower level of $S G M_{S M}$ measure is visible in the regions situated in the eastern part of the EU and in Portugal.

Summarizing the conclusions for smart growth pillars, a clearly visible situation can be noticed of the exceptionally favourable position presented by some regions compared to others. In the case of social cohesion (Figures 3 and 4) quite the opposite phenomena were observed, the regions presenting exceptionally bad situation were clearly noticeable. This mainly referred to such categories as unemployment, young people on labour market and gender equality.

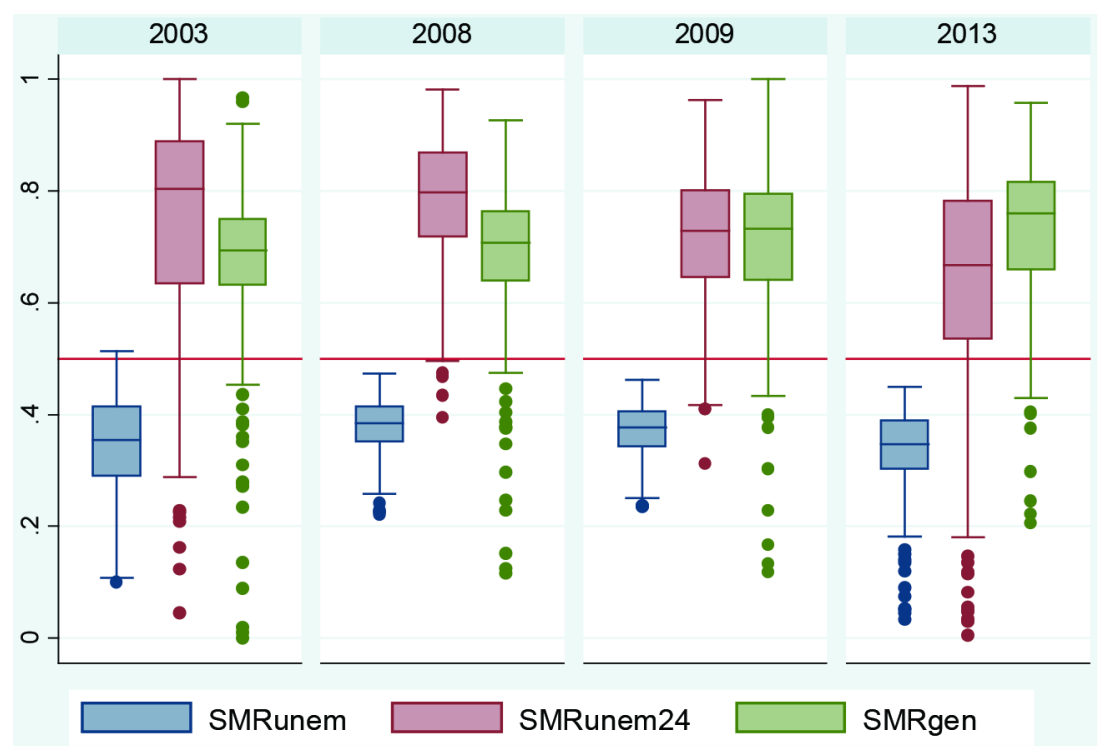

Figure 3. $S G M_{s}$ box plot for three social cohesion categories (unemployment, young people on the labour market, gender equality) (presented as stimulants) in 2003, 2008, 2009 and 2013

Source: author's compilation in STATA. 


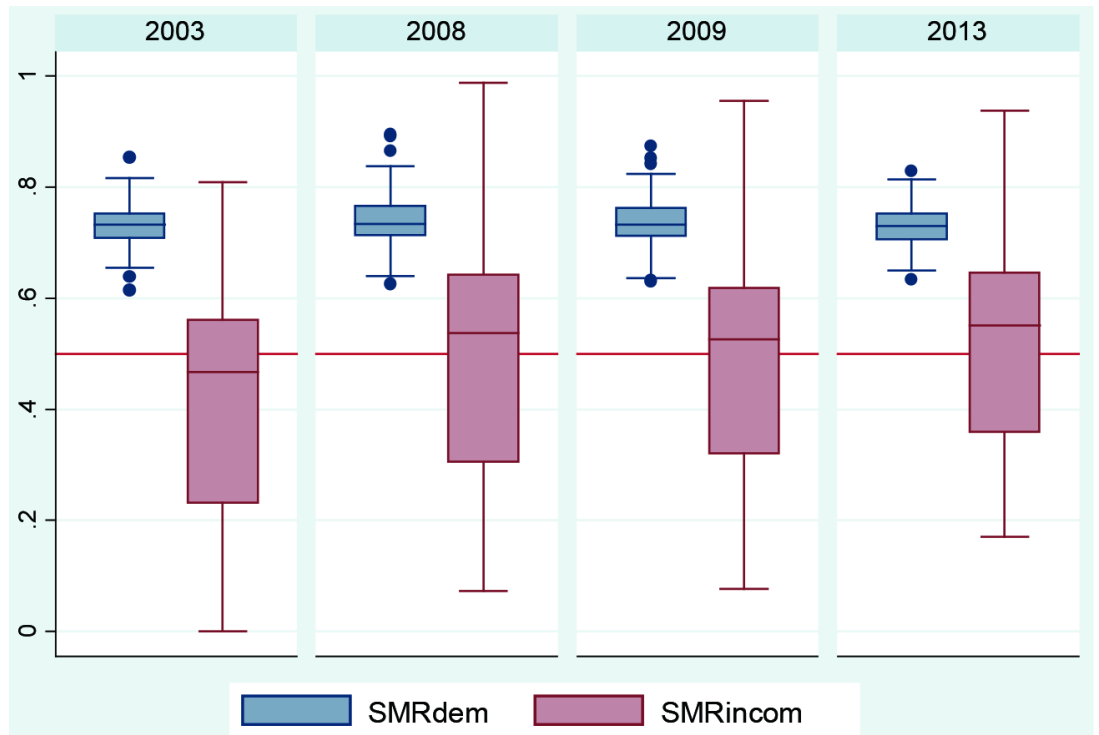

Figure 4. SGMs box plot for three social cohesion categories (demography, income) (presented as stimulants) in 2000 and 2009

Source: author's compilation in STATA.

While analysing the years 2003-2013, the period of economic crisis should be highlighted (2008-2009 in particular), when the deterioration of the majority of the most important macroeconomic indicators was recorded, including the ones referring to social cohesion. Among the five analysed categories of social cohesion the drop in a positive tendency characteristic for 2009, in comparison to 2008, was not observed in the case of gender equality only. The largest $S G M$ decrease was recorded for the category of young people in the labour market.

In the first period (2003-2008) in 2008, as compared to 2003, a significant improvement in the situation was reported for unemployment, young people on the labour market, income and gender equality. This means a lower unemployment rate referring to young people, higher income and an improvement regarding men and women employment's equality. Improvements in these categories reflected the general situation and the reduction of interregional variations (variation coefficients for unemployment, young people on the labour market in 2008 were half of the coefficients in 2003). A particularly spectacular improvement was observed in the income category (an increase of average $S G M$ level by approximately 
$20 \%$ ) and unemployment rate (an increase of average SGM level by approximately 11\%). In the next period (2009-2013) covering the crisis years, and immediately after it, many positive tendencies observed in terms of social cohesion were reversed and, as a result, a drop in average values was recorded in three categories (unemployment, young people on the labour market, demography), whereas, additionally, for the two first of them, there was an increase in interregional disproportions.

In terms of spatial variations in spatial cohesion level, using $S G M_{S O C}$ for all five categories of social cohesion altogether, the most favourable situation was linked to British, German, Austrian and Danish regions (Figure 2). In turn, the least favourable referred to southern Italian regions, Greece, Romania, Slovakia and Bulgaria.

\section{ECONOMETRIC ANALYSIS RESULTS OF THE RELATIONS BETWEEN SOCIAL COHESION AND SMART GROWTH}

The results of the econometric analysis, referring to the identification and measurement of the relations occurring between each smart growth pillar and social cohesion categories, are presented below. It was assumed that each pillar can result in different social effects in a particular region. An additional assumption was made that the relations under analysis are regionally diversified, therefore individual effects for each region were included in the appropriate panel models. Moreover, bearing in mind the observed trend changes in terms of the particular social cohesion categories (see above), an econometric analysis was conducted for the entire period (AII) and also for two sub-periods, i.e. before (I. 2003-2008) and after the crisis (II. 2009-2013).

It is worth summarizing the technical aspects of the estimated models prior to assessing the substantive merit of the analysed relationships, as well as their intensity and direction. The $\mathrm{F}$ test results, regarding the significance of regional variations, indicate significant differences between the regions. The F statistics values, either equal or significantly exceeding 50 . justify the inclusion of $\alpha_{i}$ individual, regional effects in the model, which being statistically significant improve the estimation results to a large extent. The values of determination coefficients $\left(R^{2}\right)$ - defining model adjustment to actual data - showed the level of approximately $88 \%$ and above.

For each model the first-order autocorrelation coefficient was presented and the Durbin-Watson (DW) statistics decided on its basis. Summing up, 
the assessment of models in terms of the autocorrelation processes in time series showed the occurrence of a clearly positive autocorrelation for models constructed based on the full research period (AII., $t=11$ ). The reasons of autocorrelation can be attributed to both the small (insufficient) number of factors taken into account in the model structure (in each case models had only one independent variable) and also in the analytical form of the model, which assumes a permanent, linear relationship in the entire analysed period. The assumption of a permanent relationship in the entire research period due to the results obtained in the initial analysis stage - seems overoptimistic. In the subsequent stage of the analysis an attempt was made to improve the quality of models through the estimation for sub-periods, and then the estimation of multiple regression models (in accordance with model (4) specification). After performing modelling for the particular periods the problem of autocorrelation was reduced. The best results were obtained for I. period, i.e. 2003-2008, in turn the inclusion of a larger number of variables in the model structure did not affect significantly the problem of autocorrelation and thus these results were not presented in the article. Due to the aforementioned problems with autocorrelation in the models covering the entire period (All. 2003-2013), in the next part of the study attention will be paid to the estimation results in the sub-periods before and after the crisis.

The analysis was initiated with the estimation of a single regression model for each pillar (Tables 2-4). The most significant relations with social cohesion category were identified for creativity and smart specialization pillars.

In the first period (2003-2008), a clear improvement is observed in both spheres identified as the strategic goals in the long-term growth perspective EUROPA 2020. In the case of creativity and smart specialization pillars before the crisis period (I. 2003-2008), each social cohesion category (presented as stimulants) indicated a statistically significant positive influence which confirmed the fact that the situation's improvement, in particular the social categories, was accompanied by a higher level of smart specialization and regional creativity. This confirmed the occurrence of positive and consistent tendencies for the development of a modern economy and society structure, in line with the concept of a knowledge-based economy and the improvement of social aspects adhering to the idea of a democratic society. These consistent tendencies were shaken by the 2008 crisis. While in the case of structural phenomena presenting a relatively stable nature (such as the level of education and the structure of enterprises) 
a positive growth was maintained, the situation in the selected social areas started deteriorating. As a result, negative assessments of structural parameters were obtained for unemployment, the situation of young people on the labour market and the demographic situation. In terms of income, in both periods the relationships were positive and indicated a consistent direction of change and an improvement of the situation, even in the period after the crisis. The income level presented a relative resilience to the economic downturn in 2008. The labour market, in turn, was thrown off the positive trend, which was manifested by the deteriorating situation in the years 2009-2013.

With reference to regional creativity, expressing the educational and professional specialization level in society, a statistically significant relationship was observed in all social cohesion categories: income level, unemployment level, youth situation on the labour market, and demography (Table 2).

Table 2

The estimations for regional creativity linear models (4) and particular social cohesion categories (presented as stimulants)

\begin{tabular}{|c|c|c|c|c|c|}
\hline Specification & Period & $S G M_{C R, i t}=\beta S G M_{S O C, i t}^{s}+\alpha_{i}+\varepsilon_{i t}$ & $R^{2}$ & $\begin{array}{c}\text { Test F } \\
(p \text {-value })\end{array}$ & RHO/DW \\
\hline \multirow[t]{3}{*}{$C R$ 1)SGM $M_{U N E M}$} & I.2003-2008 & $\mathbf{0 . 3 9 7} * *[0.017]$ & 0.964 & $120.7(0.000)$ & $0.323 / 0.907$ \\
\hline & II.2009-2013 & $\mathbf{- 0 . 2 7 4 * * [ 0 . 0 0 0 ]}$ & 0.971 & $120.7(0.000)$ & $0.44 / 0.79$ \\
\hline & All. 2003-2013 & $\mathbf{- 0 . 0 9 3}[0.223]$ & 0.883 & $67.5(0.000)$ & $0.844 / 0.261$ \\
\hline \multirow[t]{3}{*}{$C R$ 2)SGM $M_{U N E M_{-} 24}$} & $I .2003-2008$ & $0.121 * * *[0.000]$ & 0.961 & $107.5(0.000)$ & $0.352 / 0.855$ \\
\hline & II.2009-2013 & $-\mathbf{0 . 1 0 0} * * *[0.000]$ & 0.967 & $108.8(0.000)$ & $0.456 / 0.699$ \\
\hline & All. 2003-2013 & $-\mathbf{0 . 1 3 6} * * *[0.000]$ & 0.891 & $75.5(0.000)$ & $0.807 / 0.303$ \\
\hline \multirow[t]{3}{*}{$C R$ 3)SGM $M_{G E N}$} & I.2003-2008 & $\mathbf{0 . 1 5 8} * *[0.005]$ & 0.959 & $95.7(0.000)$ & $0.388 / 0.818$ \\
\hline & II.2009-2013 & $\mathbf{0 . 1 6 6 * * *}[0.000]$ & 0.965 & $81.7(0.000)$ & $0.471 / 0.685$ \\
\hline & All. 2003-2013 & $0.494 * * *[0.000]$ & 0.906 & $72.3(0.000)$ & $0.719 / 0.443$ \\
\hline \multirow[t]{3}{*}{$C R$ 4)SGM INCOM } & I.2003-2008 & $0.601 * * *[0.000]$ & 0.974 & $116.5(0.000)$ & $0.231 / 1,169$ \\
\hline & II. 2009-2013 & $\mathbf{0 . 1 8 5} * * *[0.000]$ & 0.966 & $80.5(0.000)$ & $0.465 / 0.678$ \\
\hline & All. 2003-2013 & $\mathbf{0 . 5 3 1 * * * [ 0 . 0 0 0 ]}$ & 0.916 & $65.3(0.000)$ & $0.827 / 0.386$ \\
\hline \multirow[t]{3}{*}{$C R$ 5)SGM $M_{D E M}$} & $I .2003-2008$ & $\mathbf{0 . 1 8 4 * * * [ 0 . 0 0 0 ]}$ & 0.96 & $100.9(0.000)$ & $0.373 / 0.845$ \\
\hline & II. 2009-2013 & $\mathbf{- 0 . 0 2 6 * *}[0.004]$ & 0.963 & $90.6(0.000)$ & $0.497 / 0.637$ \\
\hline & All. 2003-2013 & $\mathbf{- 0 . 1 1 4} * * *[0.002]$ & 0.883 & $66.4(0.000)$ & $0.84 / 0.278$ \\
\hline
\end{tabular}

$* * *$ significant at the level of $0.001, * *$ significant at the level of $0.05, *$ significant at the level of 0.1. Arellano robust standard error HAC is quoted in parentheses []. $R^{2}$ coefficient of determination. $R H O$ - coefficient of autocorrelation. $D W-$ Durbin Watson statistics of autocorrelation

Source: author's compilation in GRETL programme. 
Similar categories (as in the case of the creativity pillar) were identified as significant by single regression models, characterizing the relationships between social cohesion and smart specialization (Table 3 ). With reference to each significance level, the largest impact on regional smart specialization - shown by the developed knowledge and innovation based on services and manufacturing - was demonstrated in such qualities as income and unemployment (youth $S G M_{U N E M 24}$ and general $S G M_{U N E M}$ ). The lowest statistical significance was presented by both demographic and gender equality.

Table 3

The estimations for smart specialization linear models (4) and particular social cohesion categories (presented as stimulants)

\begin{tabular}{|c|c|c|c|c|c|}
\hline Specification & Period & $S G M_{S S, i t}=\beta S G M_{S O C, i t}^{s}+\alpha_{i}+\varepsilon_{i t}$ & $R^{2}$ & $\begin{array}{c}\text { Test F } \\
(p-v a l u e)\end{array}$ & RHO/DW \\
\hline \multirow[t]{3}{*}{ SS 1) $S G M_{U N E M}$} & I. 2003-2008 & $\mathbf{0 . 1 6 6 * * *}[0.000]$ & 0.97 & $130.5(0.000)$ & $0.144 / 1.286$ \\
\hline & II. $2009-2013$ & $\mathbf{- 0 . 0 7 5} * * *[0.000]$ & 0.986 & $231.2(0.000)$ & $0.19 / 1.133$ \\
\hline & All. 2003-2013 & $\mathbf{0 . 0 3 3}[0.411]$ & 0.938 & $124.2(0.000)$ & $0.579 / 0.698$ \\
\hline \multirow[t]{3}{*}{ SS 2) $S G M_{U N E M_{-} 24}$} & I. $2003-2008$ & $\mathbf{0 . 0 6 3} * * *[0.001]$ & 0.969 & $116.2(0.000)$ & $0.135 / 1.297$ \\
\hline & II. 2009-2013 & $\mathbf{- 0 . 0 2 1} * *[0.009]$ & 0.985 & $207.9(0.000)$ & $0.195 / 1.107$ \\
\hline & All. 2003-2013 & $\mathbf{- 0 . 0 4 1} * *[0.005]$ & 0.94 & $118.2(0.000)$ & $0.561 / 0.716$ \\
\hline \multirow{3}{*}{$S S$ 3) $S G M_{G E N}$} & I. $2003-2008$ & $\mathbf{0 . 0 7 5} *[0.016]$ & 0.968 & $131.2(0.000)$ & $0.172 / 1.249$ \\
\hline & II. 2009-2013 & $\mathbf{0 . 0 4 5} * *[0.012]$ & 0.985 & $208.5(0.000)$ & $0.194 / 1.116$ \\
\hline & All. 2003-2013 & $\mathbf{0 . 2 3 3} * * *[0.000]$ & 0.946 & $148.6(0.131)$ & $0.484 / 0.861$ \\
\hline \multirow[t]{3}{*}{$S S$ 4) $S G M_{I N C O M}$} & I. $2003-2008$ & $\mathbf{0 . 1 4 5} * * *[0.000]$ & 0.969 & $84.4(0.000)$ & $0.112 / 1.288$ \\
\hline & II. $2009-2013$ & $\mathbf{0 . 0 8 2} * * *[0.000]$ & 0.986 & $118.9(0.000)$ & $0.19 / 1.125$ \\
\hline & All. 2003-2013 & $\mathbf{0 . 2 3 5} * * *[0.000]$ & 0.946 & $96.7(0.000)$ & $0.502 / 0.856$ \\
\hline \multirow[t]{3}{*}{$S S$ 5) $S G M_{D E M}$} & I. $2003-2008$ & $\mathbf{0 . 0 6 1} * *[0.013]$ & 0.968 & $135.1(0.000)$ & $0.176 / 1.39$ \\
\hline & II. 2009-2013 & $\mathbf{- 0 . 0 1 3}[0.102]$ & 0.985 & $229.6(0.000)$ & $0.218 / 1.071$ \\
\hline & All. 2003-2013 & $\mathbf{- 0 . 0 6 6}^{* *}[0.007]$ & 0.939 & $145.3(0.000)$ & $0.566 / 0.716$ \\
\hline
\end{tabular}

As in Table 2

Source: author's compilation in GRETL programme.

Regional innovation, discussed following the restrictive assumption that it is influenced by $R \& D$ expenditure incurred by enterprises, demonstrated the relationship both before and after crises only with net disposable income level (Table 4), and indicated that in selected periods a favourable position regarding regional innovation was also manifested in the improved situation of the local population, referring to gender equality (after the crisis) and youth unemployment. In the case of youth unemployment (SGM $\left.{ }_{U N E M 24}\right)$, 
a positive relationship was identified before the crisis, indicating the improved situation of young people in the labour market, along with the increased level of business innovation measured by R\&D expenditure.

Table 4

The estimations for innovation linear models (4) and particular social cohesion categories (presented as stimulants)

\begin{tabular}{|c|c|c|c|c|c|}
\hline Specification & PERIOD & $S G M_{I N N, i t}=\beta S G M_{S O C, i t}^{s}+\alpha_{i}+\varepsilon_{i t}$ & $R^{2}$ & $\begin{array}{c}\text { Test F } \\
(p-v a l u e)\end{array}$ & RHO/DW \\
\hline \multirow{3}{*}{ INN 1) $S G M_{U N E M}$} & I. $2003-2008$ & $\mathbf{0 . 0 1 2}[0.42]$ & 0.971 & $148.1(0.000)$ & $0.374 / 0.897$ \\
\hline & II. $2009-2013$ & $\mathbf{- 0 . 0 3 4}[0.188]$ & 0.98 & $160.8(0.000)$ & $0.355 / 0.7952$ \\
\hline & All. 2003-2013 & $\mathbf{- 0 . 0 0 3}[0.873]$ & 0.956 & $182.8(0.000)$ & $0.655 / 0.58$ \\
\hline \multirow[t]{3}{*}{$I N N$ 2) $S G M_{\text {UNEM_24 }}$} & I. $2003-2008$ & $0.019 * *[0.035]$ & 0.971 & $144.8(0.000)$ & $0.375 / 0.895$ \\
\hline & II. $2009-2013$ & $\mathbf{- 0 . 0 1 1}[0.359]$ & 0.98 & $154.1(0.000)$ & $0.357 / 0.949$ \\
\hline & All. 2003-2013 & $\mathbf{- 0 . 0 2} *[0.06]$ & 0.956 & $181.0(0.000)$ & $0.651 / 0.585$ \\
\hline \multirow[t]{3}{*}{$I N N$ 3) $S G M_{G E N}$} & I. $2003-2008$ & $\mathbf{0 . 0 3 4}[0.212]$ & 0.971 & $146.7(0.000)$ & $0.37 / 0.903$ \\
\hline & II. $2009-2013$ & $\mathbf{0 . 0 5 3} * * *[0.03]$ & 0.98 & $162.5(0.000)$ & $0.353 / 0.957$ \\
\hline & All. 2003-2013 & $\mathbf{0 . 1 5 4} * * *[0.000]$ & 0.958 & $191.5(0.000)$ & $0.618 / 0.637$ \\
\hline \multirow[t]{3}{*}{$I N N$ 4) $S G M_{I N C O M}$} & I. $2003-2008$ & $\mathbf{0 . 0 8 1} * *[0.048]$ & 0.972 & $129.0(0.000)$ & 0.3650 .908 \\
\hline & II. $2009-2013$ & $\mathbf{0 . 0 8 7} * *[0.007]$ & 0.98 & $133.5(0.000)$ & $0.344 / 0.968$ \\
\hline & All. 2003-2013 & $\mathbf{0 . 1 4 1} * * *[0.000]$ & 0.958 & $161.6(0.000)$ & $0.63 / 0.617$ \\
\hline \multirow[t]{3}{*}{$I N N$ 5) $S G M_{D E M}$} & I. $2003-2008$ & $\mathbf{- 0 . 0 3 9}[0.205]$ & 0.97 & $156.4(0.000)$ & $0.37 / 0.902$ \\
\hline & II. $2009-2013$ & $\mathbf{- 0 . 0 0 3}[0.706]$ & 0.98 & $188.5(0.000)$ & $0.358 / 0.948$ \\
\hline & All. 2003-2013 & $\mathbf{- 0 . 0 5 9} * *[0.010]$ & 0.956 & $207.3(0.000)$ & $0.649 / 0.591$ \\
\hline
\end{tabular}

As in Table 2

Source: author's compilation in GRETL programme.

The next step of the conducted analysis focused on measuring the joint influence of smart growth pillars on particular social cohesion categories. Due to the low quality of models for the entire analysed period (Tables 2-4) the results for two sub-periods only were presented i.e. 2003-2008 and 20092013 (Table 7). The creativity pillar represents the statistical significant influence with social cohesion (at every level of statistical significance). A statistically significant influence was also true for smart specialization, but mostly in the first period (before the crisis). The smallest impact was reported for regional innovation. This is justified by the nature of this phenomenon. R\&D expenditure is incurred in the selected regions only and, additionally, is of an investment nature, and thus can occur in a particular period without the requirement of being continued on an ongoing basis. 
After a period of high R\&D expenditure a slowdown may occur, moreover, its impact on the environment is noticeable with a certain delay.

Similarly to the above-presented models, a reverse relationship is also observed as a result of economic crisis, for the variables reflecting the labour market situation $\left(S G M_{U N E M}\right.$ and $\left.S G M_{U N E m 24}\right)$.

Among all the social cohesion categories, the smallest relationships with smart specialization level were related to the demographic situation measure. Population growth was selected in the study in order to discuss demographic problems. SGM for demography promotes regions in which population number presents an increasing tendency, which may be interpreted as substantially facilitating socio-economic conditions. It has to be emphasized that this factor was quite rigorously defined in the model as the current year dynamics index, with reference to the previous one. Consequently, the regions which managed to improve their situation represent the ones which, in subsequent years, reported increasing tendencies in their population number (as a result of migrations and/or positive natural increase-rate) occurring at a faster pace than in previous periods.

Table 7

The estimations of linear model (5) for particular smart growth pillars and social cohesion categories (presented as stimulants) in the periods of 2003-2008 and 2009-2013

\begin{tabular}{|c|c|c|c|c|c|c|c|}
\hline \multirow{2}{*}{$\begin{array}{c}\text { Dependent } \\
\text { variable }\end{array}$} & \multirow{2}{*}{ Period } & \multicolumn{3}{|c|}{$S G M_{S O C, i t}^{s}=\sum \beta_{l} S G M_{S M, i t}^{l}+\alpha_{i}+\varepsilon_{i t}$} & \multirow{2}{*}{$R^{2}$} & \multirow{2}{*}{$\begin{array}{c}\text { Test F } \\
(p-\text { value })\end{array}$} & \multirow{2}{*}{ RHO/DW } \\
\hline & & $C R$ & $S S$ & $I N N$ & & & \\
\hline \multirow[t]{2}{*}{$S G M_{U N E M}$} & I. $2003-2008$ & $0.33 * * *$ & $0.226 * * *$ & - & 0.875 & $27.7(0.000)$ & $0.564 / 0.67$ \\
\hline & II. 2009-2013 & $-0.777 * * *$ & $-0.305^{* * *}$ & - & 0.868 & $2.6(0.000)$ & $0.338 / 0.883$ \\
\hline \multirow[t]{2}{*}{$S G M_{\text {UNEM_24 }}$} & I. 2003-2008 & $0.513 * * *$ & $0.533 * * *$ & - & 0.809 & $14.4(0.000)$ & $0.476 / 0.75$ \\
\hline & II. 2009-2013 & $-1.12 * * *$ & - & - & 0.87 & $24.5(0.000)$ & $0.424 / 0.778$ \\
\hline \multirow[t]{2}{*}{$S G M_{G E N}$} & I. $2003-2008$ & $0.127 * * *$ & $0.113^{* *}$ & - & 0.958 & $90.2(0.000)$ & $0.173 / 1.26$ \\
\hline & II. 2009-2013 & $0.295^{* * *}$ & - & - & 0.972 & $102.6(0.000)$ & $0.053 / 1.44$ \\
\hline \multirow[t]{2}{*}{$S G M_{I N C O M}$} & I. $2003-2008$ & $0.643 * * *$ & - & $0.102 * * *$ & 0.981 & $146.4(0.000)$ & $0.52 / 0.744$ \\
\hline & II. 2009-2013 & $0.347 * * *$ & $0.459 * * *$ & $0.135^{* * *}$ & 0.979 & $76.9(0.000)$ & $0.4 / 0.708$ \\
\hline \multirow[t]{2}{*}{$S G M_{D E M}$} & I. $2003-2008$ & $0.252 * * *$ & - & - & 0.9 & $36.6(0.000)$ & $0.292 / 1.07$ \\
\hline & II. 2009-2013 & - & - & - & - & - & - \\
\hline
\end{tabular}

As in Table 2

Source: author's compilation in GRETL programme.

In the last step of seeking answers to the question of whether the social cohesion situation in better developed regions is more favourable, an attempt was made to identify the cross-section relationships between the analysed 
phenomena of social cohesion and smart growth. The results of cross-section regression, in accordance with (6) specification are presented in Figure 5. The points present statistically significant (at the level of $p$-value $=0.001$ ) assessments of (6) models, which explained at least $15 \%\left(R^{2}\right)$ variability of the explanatory variable (representing one of the social cohesion categories). The key to the figures presents the range of determination coefficient values $\left(R^{2}\right)$ adopted in the subsequent years, in the models presented in the figures.
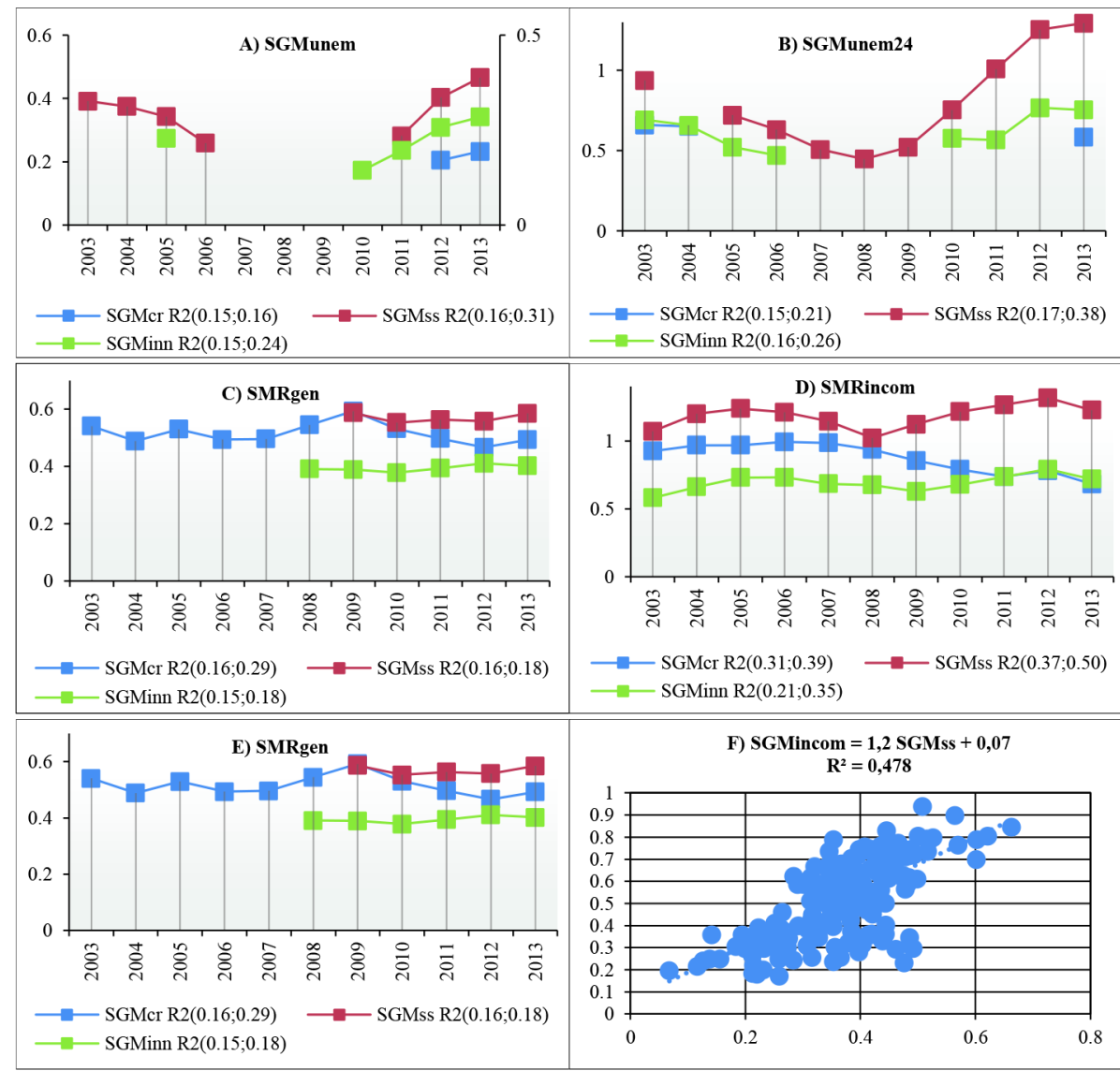

Figure 5. Linear, cross-sectional model (6) estimates (statistical significant parameters and determination coefficient $R^{2}$ at least $15 \%(0.15)$ in parentheses)

Source: author's compilation in GRETL and EXCEL programme. 
Summing up the obtained results it should be highlighted that (Figure 5):

- linear models allowed to explain only a small part of the variability referring to the particular social cohesion categories. In the case of many models the determination coefficient $\left(R^{2}\right)$ was lower than $15 \%$ (the parameters of these models are not presented on figures). The highest value of determination coefficient was characteristic for models describing the relationships of income $\left(S G M_{I N C O M}\right)$ and smart specialization $\left(S G M_{S S}\right)$ levels, for which $R^{2}$, in the worst case, amounted to $37 \%$, indicating that the model for the regional employment level in high and mid-tech enterprises in industry and knowledge-intensive services $\left(S G M_{S S}\right)$ allowed explaining $37 \%$ of income level variability. In the best model it was $50 \%$;

- all the identified dependencies are of a positive nature, which means that the regions characterized by higher smart growth level feature a higher level of a given social cohesion category;

- for each of the five social cohesion categories the highest assessments of structural parameters were obtained for smart specialization $\left(S G M_{S S}\right)$, which suggested that the strengthening of smart growth level in a region is manifested, to the highest extent, by a more favourable social situation. For example in 2013 in the regions characterized by higher smart specialization $\left(S G M_{S S}\right)$ level by one unit, a higher level of synthetic measure for income $\left(S G M_{I N C O M}\right)$ was recorded by 1.22 unit (cf. Figure $6 \mathrm{~F})$. In turn, the higher level of synthetic measure in terms of regional human capital $\left(S G M_{C R}\right)$ by one unit, or R\&D investments in business $\left(S G M_{I N N}\right)$ resulted on average in the higher synthetic assessment of household income level by 0.68 and 0.72 unit respectively.

\section{CONCLUSIONS}

The presented results aim at discussing the relationships occurring between smart growth and social cohesion. These phenomena were referred to as multivariate variables. Smart growth was described by means of three pillars: smart specialization, creativity and innovation, while social cohesion was defined from the perspective of the most important problems related to an economic situation and grouped in five categories: income, young people on the labour market, unemployment rate, gender equality, and demography.

Answering the questions put forward at the beginning of the article, it should be stated that: 
1. In the period 2003-2013 the situation of the analysed EU regions regarding smart growth was improving.

This predominantly refers to the creativity of regional human resources. Human capital (in particular measured by the level of workforce education) shows permanent growth along with the tendency towards levelling up between regions. The creativity pillar represents the fastest developing smart growth area (mean value of $S G M_{C R}$ in 2013 was $48 \%$ higher than in 2003). The regions also improved their position in the other smart growth areas, i.e. smart specialization and innovation. Also in this case its levelling was observed between regions and an average level increase (the mean value of measures for pillars in the final analysed period), i.e. in 2013 it was higher by: $S G M_{S S}-13 \%$ and for $S G M_{I N N}-17 \%$ from an average level in the first analysed year, i.e. 2003.

2. Not all social cohesion areas recorded the improvement in the analysed period.

It is worth emphasizing the diverse nature of the analysed phenomena. Such socio-economic phenomena as unemployment, income, investments (including R\&D) and manufacturing are subject to fluctuations (prosperity), which is reflected in the tendency towards a high increase or decrease, especially visible in the short term. At the other end, we have the example of human capital which as the sum of collected knowledge, skills and experience is not subject to such strong short-term fluctuations. In the analysed periods of several years covered by the assessment human capital is accumulated, which is manifested in the continuously growing number of HRST or tertiary education population obtaining qualifications and gaining experience useful in science and technology. At the same time other phenomena, less resilient to fluctuations, presented periodical ups and downs.

Among social cohesion categories an improvement of the average situation assessment in the cross-section of regions in the final analysed period (2013), against the initial one (2003) was recorded for two categories only: gender equality and income. Particularly positive is the continuous increase in the average net disposable income level of households. At the same time for both of these areas, regional development level differences were decreasing. In the case of demographics the situation did not change much and the average value of $S G M_{D E M}$ remained in the final analysed period, at the same level as in the initial one, suggesting the growth of population at an unchanged level. The deterioration was, in turn, recorded for both categories referring to unemployment $\left(S G M_{U N E M}\right.$ and $\left.S G M_{U N E m 24}\right)$. In 
this context the growing disproportions in the availability of jobs for young people in the recent few years should be assessed as particularly negative.

3 . The crisis had a significant impact on the majority of the analysed socioeconomic categories and, in particular, on the selected social areas.

In almost all social categories the situation was worse in 2008-2009 in spite of the improvement recorded in the period 2007-2008 (and earlier). The category of gender equality $S G M_{G E N}$ was an exception, in which in 2009 against 2008 the highest improvement was observed. In the case of the income after the situation deterioration in 2009 the return to the growth path was recorded. In the other social cohesion categories the situation got worse, in particular with reference to young people on the labour market. In both categories, presenting the situation of the unemployed (SGM UNEM and $\left.S G M_{U N E m 24}\right)$, the ongoing deterioration of the situation was observed after the crisis till the end of the analysed period.

In the case of smart specialization, the largest improvement observed in each consecutive year, was in 2009. This can be interpreted as the resilience of employment in the knowledge sectors to the financial and economic turmoil resulting from the 2008 crisis $^{6}$. At this point it is worth citing other research results by Jaegers, Lipp-Lingua, Amil (2013) from Eurostat and Bal-Domańska (2014), according to which "after the crisis in the period 2010-2011 the growth rate in high HMMS group was higher than in other groups. In terms of high-technology manufacturing, the Eurostat study concludes that the recovery was driven by pharmaceuticals, and the aircraft and aerospace equipment".

In the case of creativity pillar, no changes were recorded in the average level of the discussed phenomenon in the crisis years. A continuous growing tendency was observed in the entire period (which corresponds to the nature of this phenomenon and expectations in this matter). In turn, for the innovation pillar only a slight slowdown in improvement was noted in the average level of this phenomenon after 2009.

4. Smart growth situation improvement was accompanied by better social cohesion in the analysed regions.

Among the identified social cohesion categories, a clear relationship between smart growth pillars was visible for household net disposable incomes which were growing along with the increasing level of smart specialization, creativity and innovation pillars. It was also observed that in

\footnotetext{
${ }^{6}$ This variable is expressed as the structure indicator presenting the share of the selected sectors in full. Such a change should be of a relative nature resulting from the reduced employment in other sectors.
} 
the case of regional creativity and smart specialization most social cohesion categories were recognized as the statistically significant factors.

The obtained results emphasize the significance of endogenous factors, related to human capital, for social cohesion. Regional creativity $S G M_{C R}$ manifested by the skills and education of the workforce presented the highest consistency with social cohesion improvement. The relations with smart specialization, defined as human resources and human capital in high and medium high-technology manufacturing and knowledge-intensive services, were also recognized as significant (however, to a lesser extent). The smaller influence of knowledge-based sectors $S G M_{S S}$ can be explained by their fragmentation, since they present only a part of the labour market, as opposed to regional creativity covering the entire economy. Nevertheless, having observed the relatively small difference in the impact level of both $S G M_{C R}$ and $S G M_{S S}$, it can be concluded that knowledge-based sectors have a relatively crucial significance for the accomplishment of social cohesion. A positive (even though the smallest among the discussed smart growth pillars) relationship with social cohesion was also recorded for regional innovation, defined as the investment decisions made by enterprises in the area of research and development (R\&D).

Positive relationships between smart growth were analysed both in terms of the cross-section relations and cross-temporal ones (based on panel models). Based on panel data it was possible to carry out the phenomena modelling in terms of variations of regional development level considering time changes. The most important conclusions resulting from this part of the analysis were as follows: confirming the lack of possibility to describe the analysed relations between social cohesion and smart growth in the entire analysed period, caused by the lasting change in the tendencies of selected social categories, as a result of which the obtained model assessments were either irrelevant or unreliable due to the strong autocorrelation processes. Modelling in two sub-periods: before (2003-2008) and after the crisis (20092013) was considered correct.

Referring to the regional smart growth level, as the social development factor, regional creativity $S G M_{C R}$ should be identified as statistically substantive for each of the assessed social categories in all periods (except the demographical post-crisis processes). Additionally, smart specialization was an important social cohesion factor in the initial period of the conducted analysis (before the crisis). Regional innovation - as one of the three smart growth pillars - had an important impact only on the change of income level in both analysed periods. The most accurate picture of relationships between 
the regional smart growth and the level of social development was obtained for the gender equality category.

The cross-section analysis allowed presenting positive relationships between social cohesion and smart growth pillars in all the analysed years. At the same time it should be observed that the level of smart growth, in spite of being statistically substantive, is capable of explaining the crosssectional variations of the analysed social cohesion dimensions only to a small extent.

This can be interpreted in the following way: the regions featuring a higher level of creativity, innovation and smart specialization, experience at the same time a higher level of social cohesion. This phenomenon was particularly visible after the crisis. Moreover, regions characterized by a higher smart specialization level present a more favourable situation in terms of social cohesion, especially in access to the labour market for young people.

\section{REFERENCES}

A Strategy for Smart, Sustainable and Inclusive growth, European Commission, Communication from the Commission EUROPE 2020. Brussels, 3.3.2010.

Akaike, H., A New Look at the Statistical Model Identification, IEEE Transactions on Automatic Control, Vol. 19, No 6, pp. 716-723, 1974.

Arellano, M., Panel Data Econometrics. Oxford University Press, Oxford, 2003.

Asheim, B., Industrial Districts as "Learning Regions". A Conditions for Prosperity. Studies in technology innovation and economic policy, University of Oslo, Oslo 1995.

Bal-Domańska, B., The Impact of Economic Crisis on Convergence Processes in Regions with Different Level of Smart Specialization, Prague Economic Papers 2016 (DOI: http://dx.doi.org/10.18267/j.pep.574)

Bal-Domańska, B., Wilk, J., Gospodarcze aspekty zrównoważonego rozwoju województw wielowymiarowa analiza porównawcza [Economic Aspects of Regional Sustainable Growth - Multivariate Comparative Analysis], „Przegląd Statystyczny” No 3-4, pp. 300$-322,2011$.

Baltagi, B. H., Econometric Analysis of Panel Data, Third edition. John Wiley \& Sons, Ltd., Chichester, 2005.

Bąkowski, A., Siemaszko, A., Snarska-Świderska, M., Jak zostać regionem wiedzy i innowacji [How to Become the Region of Knowledge and Innovation], pp. 38-57. TWIGGER, Warsaw, 2007.

Cichy, K., Kapitat ludzki i postęp techniczny jako determinanty wzrostu gospodarczego [Human Capital and Technical Development as Determinants of Economic Growth]. Instytut Wiedzy i Innowacji, Warsaw, 2008. 
Chen, D. H. C., Dahlman, C. J., The Knowledge Economy, the KAM Methodology and World Bank Operations (October 19, 2005). World Bank Institute Working Paper No. 37256. Available at SSRN: https://ssrn.com/abstract $=841625$

Dominiak, J., Churski, P., Rola innowacji w kształtowaniu regionów wzrostu i stagnacji w Polsce [The Role of Innovation in Creating the Regions of Growth and Stagnation], „Studia Regionalne i Lokalne” No 4(50), pp. 54-77, 2012.

Dziechciarz, J., Ekonometryczne modelowanie procesów gospodarczych. Modele ze zmiennymi i losowymi parametrami [The Econometric Modelling Economic Processes. Models with Changeable and Random Parameters], „Monografie i opracowania”, No 95, Wrocław, 1993.

Fiedor, B., Microeconomic and Institutional Forms and Methods of Integrated Smart-growth Influence of State on the Economy under Transformation. An Attempt at the Identification and Classification of Major Instrument Groups, "Ekonomia" 2(14), pp. 11-25, 2011.

Florida, R., The Learning Region [in:] Acs J. Z. (ed.), Regional Innovation, Knowledge and Global Change. Pinter, London, 2000.

Greene, W. H., Econometric Analysis. Pearson Education International, New Jersey, 2003.

Hellwig, Z., Zastosowanie metody taksonomicznej do typologicznego podziału krajów ze względu na poziom ich rozwoju oraz zasoby i strukturę wykwalifikowanych kadr [The Application of Taxonomic Method for Typological Division of Countries Regarding Their Development Level as Well as the Resources and Structure of Qualified Personnel], "Przegląd Statystyczny", No 4, pp. 307-327, 1968.

Herbst, M. (ed.), Kapitat ludzki i kapitat spoteczny a rozwój regionalny [Human Capital and Social Capital vs. Regional Development]. SCHOLAR, Warsaw, 2007.

Hsiao, Ch., Analysis of Panel Data, Cambridge University Press, Cambridge, 1986.

Jaegers, T., Lipp-Lingua, C., Amil, D., High-technology and Medium-high Technology Industries Main Drivers of EU-27's Industrial Growth, "Statistics in Focus 1", Eurostat, 2013.

Kawa, P., Rola wiedzy $i$ innowacji $w$ stymulowaniu wzrostu gospodarczego [The Role of Knowledge and Innovation in Stimulating the Economic Growth] [in:] Piech, K., Skrzypek, E. (eds.) „Wiedza w gospodarce, społeczeństwie i przedsiębiorstwach: pomiary, charakterystyka, zarządzanie" [The Knowledge in Economy, Society and Enterprises: Measures, Characteristics, Management], pp. 16-29. Instytut i Innowacji, Warsaw, 2007.

Krugman, P., Development Geography, and Economic Theory. Ohlin Lectures. MIT Press, Cambridge-London, 1995.

Krugman, P., Increasing Returns and Economic Geography, “Journal of Political Economy”, Vol. 99, No 3, 1991.

Lucas, R. E., On the Mechanics of Economic Development, "Journal of Monetary Economics", Vol. 22, No 1, 1988.

Maddala, G. S., Ekonometria [Econometry]. PWN, Warsaw 2006.

Markowska, M., Strahl, D., A Multicriteria Classification of the European Regional Space in Terms of Economic and Social Cohesion and Smart Growth, [in:] Pociecha, J., Models and Methods for Analysing and Forecasting Economic Processes, pp. 64-82. Cracow University of Economics Press, Cracow, 2014. 
Molle, W., Cappelin, R., Regional Impact of Community Policies in Europe, "Business \& Economics", Avebury, 1988.

Myrdal, G., Economic Theory and Underdeveloped Regions. Duckworth, London, 1957.

Nowak, E., Zarys metod ekonometrii. Zbiór zadań [The Outline of Econometric Methods. A Collection of Problems]. WN PWN, Warsaw, 2006.

OECD, Innovation-driven Growth in Regions: The Role of Smart Specialisation, OECD 2013.

Perroux, F., Note sur la notion de pole de croissance, Economique appliquee. Vol. 1-2, 1955.

Romer, P., Endogenous Technological Change, "Journal of Political Economy” No 5, pp. 71$-102,1990$.

Romer, P., Increasing Returns and Long-run Growth, "Journal of Political Economy", pp. 1002-1037, 1986.

Strahl, D., Innowacyjność europejskiej przestrzeni regionalnej a dynamika rozwoju gospodarczego [Innovativeness European Regional Space vs Dynamics of Economic Growth]. Publishing House of Wrocław University of Economics, Wrocław, 2010.

Strahl, D. (ed.), Taksonomia struktur $w$ badaniach regionalnych [Taxometrics Structures in Regional Research]. Publishing House of Wrocław University of Economics, Wrocław, 1998.

Świtała, J. Wplyw kapitału ludzkiego na rozwój regionalny w Polsce w kontekście gospodarki opartej na wiedzy [The Influence of Human Capital on Regional Development in Poland in the Context of Knowledge Based Economy] [in:] Okoń-Horodyńska, E., Pangsy-Kania, S. (eds.) „Innowacyjność w budowaniu gospodarki opartej na wiedzy w Polsce” [Innovation in Knowledge-based Economy Construction in Poland], pp. 75-90. The Knowledge and Innovation Institute, Warsaw, 2007.

Walesiak, M., Uogólniona miara odległości w statystycznej analizie wielowymiarowej [Generalised Distance Measure in Statistical Multivariate Analysis]. Publishing House of Wrocław University of Economics, Wrocław, 2006.

Wooldridge, J. M., Econometric Analyses of Cross Section and Panel Data. Massachusetts Institute of Technology, 2002.

European Commission, Communication from the Commission to the European Parliament, the Council, the European Economic and Social Committee, and the Committee of the regions, (SEC(2010) 1183), Brussels, 2010.

Zeliaś, A. (ed.), Taksonomiczna analiza przestrzennego zróżnicowania poziomu życia $w$ Polsce $w$ ujęciu dynamicznym. Publishing House of Cracow Economic University, Cracow, 2000.

Received: April 2013, revised: June 2017 